\title{
Ecological responsiveness and corporate real estate
}

Citation for published version (APA):

Eichholtz, P. M. A., Kok, N., \& Quigley, J. M. (2016). Ecological responsiveness and corporate real estate. Business \& Society, 55(3), 330-360. https://doi.org/10.1177/0007650315575118

Document status and date:

Published: 01/03/2016

DOI:

10.1177/0007650315575118

Document Version:

Accepted author manuscript (Peer reviewed / editorial board version)

\section{Please check the document version of this publication:}

- A submitted manuscript is the version of the article upon submission and before peer-review. There can be important differences between the submitted version and the official published version of record.

People interested in the research are advised to contact the author for the final version of the publication, or visit the DOI to the publisher's website.

- The final author version and the galley proof are versions of the publication after peer review.

- The final published version features the final layout of the paper including the volume, issue and page numbers.

Link to publication

\footnotetext{
General rights rights.

- You may freely distribute the URL identifying the publication in the public portal. please follow below link for the End User Agreement:

www.umlib.nl/taverne-license

Take down policy

If you believe that this document breaches copyright please contact us at:

repository@maastrichtuniversity.nl

providing details and we will investigate your claim.
}

Copyright and moral rights for the publications made accessible in the public portal are retained by the authors and/or other copyright owners and it is a condition of accessing publications that users recognise and abide by the legal requirements associated with these

- Users may download and print one copy of any publication from the public portal for the purpose of private study or research.

- You may not further distribute the material or use it for any profit-making activity or commercial gain

If the publication is distributed under the terms of Article $25 \mathrm{fa}$ of the Dutch Copyright Act, indicated by the "Taverne" license above, 


\section{Ecological}

Responsiveness and

Corporate Real Estate
Business \& Society

$|-3|$

(C) The Author(s) 2015

Reprints and permissions: sagepub.com/journalsPermissions.nav DOI: $10.1177 / 00076503155751 \mid 8$

bas.sagepub.com

@SAGE

\title{
Piet M. A. Eichholtz', Nils Kok', and John M. Quigley²
}

\begin{abstract}
Firms' real estate choices significantly affect their sustainability, due to real estate's impact on the natural environment. This paper investigates the ecological responsiveness of firms in specific industries by analyzing the decisions these firms make in occupying office space. We analyze the decisions of more than $1 \mathrm{I}, 000$ tenants to choose office space in green buildings or in, otherwise comparable, conventional buildings nearby. Controlling for building quality and location, we find that corporations in the oil and banking industries, as well as non-profit organizations, are among the most prominent green tenants. Furthermore, measures of an industry's human capital intensity are positively related to the propensity to lease green office space. These empirical findings confirm the theoretical framework on economic advantage and institutional pressure as important determinants for the ecological responsiveness of firms.
\end{abstract}

\section{Keywords}

sustainability, green real estate, corporate tenants

There is an increasing societal interest in the sustainability of the built environment, motivated by the recognition that buildings and their associated construction activity have a significant environmental impact. Indeed, the

\footnotetext{
IMaastricht University, The Netherlands

2University of California, Berkeley, USA
}

\section{Corresponding Author:}

Piet M. A. Eichholtz, Professor of Finance and Real Estate, School of Business and Economics, Maastricht University, P.O. Box 616, 6200MD Maastricht, The Netherlands.

Email: p.eichholtz@maastrichtuniversity.nl 
demand for more efficient, "green" real estate—real estate characterized by exemplary environmental performance - is on the rise throughout the developed world. Examples range from a "green campus" built by Chevron in Louisiana to the energy-efficient headquarters of Deutsche Bank in Frankfurt am Main, Germany. In addition, although commercial real estate markets in many countries have endured major contractions in recent years, the number of green buildings is rapidly increasing (Kok, McGraw, \& Quigley, 2011).

The increasing importance of more efficient buildings may have several implications for financial intermediaries. First, from the perspective of the company, integrating sustainability in the management of real property can be important for firms seeking to adopt more ecologically responsive business practices, for example through cost reductions, as energy costs amount to nearly $10 \%$ of total housing cost. The strategic choices that firms make in the sustainability of their real estate may thus affect the performance of these firms, as well as the performance of their de facto real estate providers - their landlords. Indeed, firms' landlords, or asset owners, are the second group that may be affected by the choice for sustainable real estate. For real estate investment trusts (REITs), which are among the main providers of corporate space, there is empirical evidence that the financial markets take account of the sustainability of the portfolio: REITs' ownership of sustainable assets is related to a better credit rating and lower cost of debt (Eichholtz, Kok, \& Yonder, 2013). Third, the (equity) capital providers of these institutional landlords increasingly demand sustainable business practices or "socially responsible investments" (SRI). ${ }^{1}$ For example, more than 60 of the world's premier institutional investors are screening the sustainability performance of REITs through the Global Real Estate Sustainability Benchmark (GRESB), which measures the sustainability of these landlords.

To explore the implications of green building on financial intermediaries in more detail, this article investigates corporate choices with respect to sustainability in the real estate sector. There is a significant body of research on the ecological responsiveness of firms, following the seminal work by Bansal and Roth (2000). An important example is Ramus and Montiel (2005), who study the determinants of corporate environmental commitment. Other examples are Aragón-Correa and Rubio-López (2007), who study environmental commitment in the food industry, and Linnenluecke and Griffiths (2010) who look at the effect of corporate culture on sustainability. Recent literature on real estate and sustainability has studied the economic implications of green office buildings in the United States, documenting that green buildings command premium rental rates and sales prices (Eichholtz, Kok, \& Quigley, 2010). 
This article builds on the Ramus and Montiel (2005) framework, and it extends their analysis in four ways. First, Ramus and Montiel (2005) study just 10 firms to establish industry differences in environmental policy implementation. The present authors are able to employ a sample of more than 3,100 tenants in 1,180 green office buildings and a control sample of approximately 8,000 tenants in 4,000 conventional office buildings, allowing for stronger statistical inferences at the industry level. Second, Ramus and Montiel (2005) had to exclude certain industries from their analysis, due to lack of data, analyzing variation in ecological responsiveness in four industries. We do not face a similar problem, and are able to analyze 10 different industries. Third, Ramus and Montiel (2005) investigate the implementation of environmental decisions only for firms that had already committed to an environmental policy, whereas we are able to study a more diverse set of firms, likely having more heterogeneity in the stance regarding sustainable development. Last, Ramus and Montiel (2005) exploit a survey to assess environmental policy implementation, whereas our proxy allows us to observe corporate actions directly, through these corporations' decisions regarding the use of green versus conventional office space.

The article first develops hypotheses about the types of industries that are more likely to choose green space rather than conventional space. The authors then investigate these hypotheses, using hand-collected data on the identity and industry characteristics of tenants in green buildings in the United States. We adopt a working definition of green office buildings, as those certified by either the Energy Star or the Leadership in Energy and Environmental Design (LEED) program. ${ }^{2}$ We also construct a control sample of other, conventional office buildings, closely matched on geographical characteristics.

The descriptive statistics reveal that firms in the oil industry and in the financial services industry tend to be the largest occupiers of green office buildings. The empirical analysis shows that companies in the mining and construction industry, as well as the government and government-related organizations, are systematically more likely to lease green office space rather than conventional space, compared with corporate tenants in other industries. Furthermore, employee skill intensity and compensation are positively related to corporate use of green office space. This positive relationship confirms hypotheses about the determinants of corporate ecological responsiveness.

Our findings provide important information for financial intermediaries. From the perspective of the company, this study shows that corporate leasing decisions can facilitate the implementation of an ecologically responsible strategy, and that real estate can be a tangible element of the ecological responsiveness of firms in specific industries. Interestingly, firms within the 
financial services industry turn out to be among the most intensive users of green office space. For the providers of space - often REITs - the effect of a demand-pull for more green real estate also has implications for their portfolio strategy, and for their ability to raise capital and the cost of that capital: REITs with more sustainable assets have better credit ratings and pay lower interest rates on their debt (Eichholtz, Kok, \& Yonder, 2013). From the perspective of institutional investors, which increasingly hold their real estate exposure through stakes in REITs, the sustainability of real estate assets is relevant for the performance of the real estate companies and funds they own (Eichholtz, Kok, \& Yonder, 2012). Besides that, the sustainability of their real estate holdings may also reflect the environmental stance of institutional investors.

The remainder of this article is organized as follows. The section "Ecological Responsiveness and Real Estate" summarizes previous work on the ecological responsiveness of private firms, and we develop hypotheses predicting the likelihood that firms in different industries will choose to "rent green." The section "Data and Analysis" provides an overview of the data, the methods, and some descriptive statistics. The "Results" section presents results of the statistical analysis. The "Discussion" section provides a discussion and conclusions.

\section{Ecological Responsiveness and Real Estate}

Traditional models in the environmental literature identify four main determinants of corporate ecological performance: economic opportunities, stakeholder pressure, legislation, and ethical motives (Bansal \& Roth, 2000). Assuming that companies within the same industry are exposed to similar types of legislation and economic incentives, these determinants can be generalized to the industry level. For example, companies in the financial services industry compete for human capital in the same labor market, and may thus adopt similar policies and strategies to attract employees.

Empirically, Ramus and Montiel (2005) analyze the commitment to specific environmental policies, and the implementation of those policies, across four industry sectors. They show that firms from different industries follow similar patterns in their commitment to a set of environmental policies, but there are significant industry differences in the implementation of those policies. In the same spirit, we further advance the argument that companies in different industries will vary in their implementation of environmental policies. We develop four testable hypotheses, using corporate leasing decisions as a proxy for the actual environmental commitment of an industry. 


\section{Economic Advantage From Ecological Responsiveness}

Economic advantage as a motivation for ecological responsiveness is closely related to the financial performance of the firm. Active implementation of an environmental policy-beyond just complying with environmental regulation - is costly. Konar and Cohen (2001) estimate that U.S. firms invest a combined amount of some $1.5 \%$ to $2 \%$ of GDP annually on environmental policies, and these expenditures may crowd out other productive investments (Palmer, Oates, \& Portney, 1995). Nevertheless, there appears to be a positive association between corporate environmental performance and corporate financial performance (Karpoff, Lott, \& Rankine, 1999; Klassen \& McLaughlin, 1996; Konar \& Cohen, 2001).

The positive effect of environmental policies on financial performance may materialize following cost reductions by lowering input and waste disposal costs (Porter \& Van der Linde, 1995). Green buildings can play an important role in this regard, as the operating costs of such buildings may be substantially lower, even if their rents are generally higher. For commercial buildings, energy — an important element of sustainability — represents a significant expense in the operation of buildings, with energy costs at nearly $10 \%$ of total housing costs, on average. Anecdotal evidence shows that LEED-certified buildings, on average, use 30\% less energy than conventional buildings (Kats, 2003), and it is claimed that the energy savings on buildings with an Energy Star label are almost $40 \%$. Thus, using green buildings may have a direct impact on total housing costs.

Cost reductions from the implementation of environmental policies typically most affect resource-intensive industries in the primary and secondary sectors, as documented by Ramus and Montiel (2005). However, cost savings from leasing more efficient buildings are most significant for firms active in sectors that tend to have office-space-intensive operations, which is more likely for firms in the tertiary industry (the service sector). Firms operating in the service sector thus may also be more likely to rent green space than firms in other sectors.

Another, more indirect, benefit that may follow from the occupancy of a green building is an increase in employee productivity. Several studies have reported a positive correlation between a building's internal environment (such as its indoor air quality) and employee health and productivity. (Danna \& Griffin, 1999, review the literature on health and well-being in the workplace; see also Hoffman, Wood, \& Kreiss, 1993). The potential gains of reduced sick leave and increased productivity are substantial, and given that staff costs represent a major share of total expenditures for the average firm, the potential financial benefits from improved productivity are substantial 
(Edwards, 2006; Nelson, 2007). A recent paper by Edmans (2011) shows that corporate financial performance is positively related to employee satisfaction, which is not only affected by pecuniary benefits but also by the quality of working conditions.

And even if green real estate did not make a firm's existing work force more productive, it could attract a more productive workforce. This attractiveness may arise from an improved corporate reputation deriving from a commitment to green values. Corporate reputation has been documented to be an important determinant of job choice (Gatewood, Gowan, \& Lautenschlager, 1993), and therefore in acquiring human capital. Indeed, T. N. Bauer and Aiman-Smith (1996) show that firms having a positive attitude toward the natural environment are regarded as more attractive employers than otherwise comparable firms without such an attitude. As human capital is viewed as a key source of value creation in modern firms (Zingales, 2000), the attraction and retention of employees is especially important in economies and industries where skilled employees are scarce and skills are inelastically supplied. Henriques and Sadorsky (1999) show that the perceived importance of organizational stakeholders (e.g., the workforce) plays a large role in determining the managerial attitude toward the environment.

Thus, a positive stance toward the natural environment can increase success in hiring and retaining high-quality human capital. The degree to which human capital is important for firms is affected by the industry the firm operates in, and we argue that human capital is likely to be most salient for organizations in the service industry. For example, the enhanced indoor air quality arising from an improved building structure, and from better heating, cooling, and ventilation systems, is most beneficial for firms largely dependent on highly trained workers, such as firms in the financial industry or in professional services. This relationship results in the following hypotheses:

Hypothesis 1: Industries that are dependent on high levels of human capital, such as the service sector, will be more likely to rent office space in green buildings.

Hypothesis 2: Space-intensive industries, such as the service sector, will be more likely to rent office space in green buildings.

\section{Institutional Pressure and Ecological Responsiveness: Legitimacy and Financial Market Reputation}

Institutional pressure as a determinant of ecological responsiveness is strongly related to reputation and credibility with a firm's stakeholders. The use of green space may signal that a firm has a long-run commitment to the 
environment. So the occupancy of green buildings may translate into an improved reputation, which is important for investors. Investors are powerful corporate stakeholders (Mitchell, Agle, \& Wood, 1997), and the investment community has embraced the concept of SRI with enthusiasm. SRI assets under management increased from $\$ 639$ billion in 1995 to $\$ 2.71$ trillion in 2007 (Social Investment Forum [SIF], 2007). Investors such as APG in the Netherlands, Hermes in the United Kingdom, and TIAA-CREF in the United States have implemented SRI strategies, which are consistently communicated to their stakeholders. ${ }^{3}$

Barnea, Heinkel, and Kraus (2005) report that investors following a SRI approach can induce polluting firms to reform, and Henriques and Sadorsky (1996) find that the environmental policies of firms are responsive to shareholder pressure. Non-governmental organizations (NGOs) also increasingly use a SRI approach - by investing in SRI mutual funds - to influence firms to adopt corporate social responsibility (CSR) and specific environmental policies (Guay, Doh, \& Sinclair, 2004).

SRI strategies typically imply that investors avoid corporations that cause social injury or environmental damage (Spicer, 1978). This "negative screening" may lead institutional investors to be systematically underinvested in so-called "sin" stocks (Hong \& Kacperczyk, 2009). It is likely that corporations with environmentally sensitive operations are exposed more directly to the risk of exclusion, providing a strong incentive for the adoption and implementation of an environmentally responsive strategy.

If leasing green office space leads to a superior corporate reputation, this may enable firms to attract investors more easily and at better market rates (Milgrom \& Roberts, 1986). Some empirical studies show that companies with highly developed environmental engagement are able to obtain better credit ratings, thereby lowering the cost of debt (Bassen, Hölz, \& Schlange, 2006). Derwall and Verwijmeren (2007) show that these firms tend to have a lower cost of equity.

Bansal and Clelland (2004) find that firms with low environmental legitimacy can reduce the associated negative stock performance effects by expressing an active commitment to the natural environment. Leasing green real estate may be a straightforward way to express that commitment, signaling the superior social responsibility of the tenants who locate there. Thus, ecological responsiveness in corporate leasing decisions could potentially help in offsetting a negative corporate image or in improving the reputation of firms in objectionable industries.

The likelihood of becoming a target of environmental litigation and public scrutiny depends on the industry type. For example, firms in environmentally sensitive industries are more exposed to media visibility, which shapes the 
public's view of firm activities (Fombrun \& Shanley, 1990). Henriques and Sadorsky (1999) find that the firms engaging most actively in environmental activities tend to place special importance on environmental industry groups.

Thus, the discipline of financial markets may cause firms to implement active CSR policies. Especially for firms with environmentally sensitive operations, the risk of negative screening by investors is likely to be important, and through attention from the media and NGOs, these firms are also more exposed to public scrutiny from consumers. Firms differ in the environmental sensitivity of their operations especially across industries, although these differences are likely to be less apparent within an industry. This variation leads to the following hypothesis:

Hypothesis 3: Industries characterized by environmentally sensitive operations will be more likely to lease green office space.

\section{Environmental Responsibility}

Although the attention of investors is focused understandably on firm profits, there is a distinct group of organizations for which the non-financial utility from pursuing an active environmental policy exceeds the potential monetary costs of such a policy. The concept of environmental ideology (Kahn, 2007) suggests that non-profit organizations and government agencies may be more active in environmental engagement than purely profit-maximizing firms. As Energy-Star-labeled office buildings are known to emit far less carbon than conventional buildings (Eichholtz, Kok, \& Quigley, 2013), leasing green buildings may be a logical step for these organizations, even if the rents are higher.

Furthermore, first-movers and early-adopters of environmental innovations are often those parties for whom monetary gains are of secondary importance, and the public sector is relatively eager to demonstrate its environmental engagement through leasing space in green buildings, because it is "the right thing to do" (Wood, 1991).

Finally, for a public sector trying to "nudge" society toward reduced energy consumption and lower carbon emissions, leading by example is an alternative to regulation. As such a policy does not put a direct-financialburden on certain groups of consumers or manufacturers, it may be more palatable politically than implementing regulation. These considerations lead to the fourth hypothesis, again formulated at the industry level:

Hypothesis 4: The public sector and other non-profit institutions will be more likely to lease green space. 
In assessing the determinants of ecological responsiveness, we follow an industry-level approach, as industry differences have been documented to play a crucial role in ecological responsiveness. Field cohesion, "the intensity and density of formal and informal network ties in an organizational field" (Bansal \& Roth, 2000, p. 730), is an important determinant of a firm's environmental performance. Field cohesion is likely to be strong within industries and less strong across industries (Ramus \& Montiel, 2005). It would therefore be difficult to find meaningful results in a broad firm-level analysis of ecological responsiveness; the firm-level effects would be dominated by the industry influences.

This choice arises also from our interest in industry-level differences in the motivations of firms to opt for commercial space in green buildings. In addition, we have access to a large number of observations across different industries, but we lack firm- or establishment-level data. Moreover, we observe publicly listed, privately traded, and non-profit tenants, as well as the government and government-related entities. Systematic corporate information (such as financial metrics) is available only for the former, which inhibits a comprehensive firm-level analysis.

We investigate how the motivations to rent green office space differ across industries. Some industries will have a higher likelihood of leasing green office space than others: the economic advantage hypothesis is related to operational costs and human capital considerations, and therefore likely to play an important role in the service sector. The first institutional pressure hypothesis is linked to corporate reputation, and therefore likely to be more salient in environmentally sensitive industries, such as mining and oil. The motive of environmental responsibility (the second institutional pressure hypothesis) is probably most prevalent for governmental and non-profit organizations.

\section{Data and Analysis}

To empirically test the four hypotheses, the authors collected information on tenants in commercial office buildings that have received an Energy Star or LEED certification. These labels represent the most widely used certifications of green buildings in the United States.

Energy Star was established in 1992 as a voluntary labeling program designed to classify and promote energy-efficient products. The Energy Star label for commercial buildings was adopted in 1995. The label has been promoted as an efficient way to identify energy-efficient buildings and is marketed as an indication of better environmental protection, but it focuses solely on energy consumption and does not measure other green characteristics.

Commercial properties can receive an Energy Star certification if the source energy use of the building, as certified by a professional engineer, 
achieves certain specified benchmark levels. The benchmark is chosen such that the label is awarded to the top quarter of all comparable buildings ranked in terms of source energy efficiency.

The LEED rating system has been developed to encourage the "adoption of sustainable green building and development practices." LEED uses a broad definition of building sustainability and is based on a wide range of criteria. The requirements for certification of LEED buildings include such factors as "site selection," "brownfield redevelopment," and the availability of "bicycle storage and changing rooms," as well as energy performance. An external consultant evaluates a building on criteria in six categories to establish the LEED rating. ${ }^{4}$ It is claimed that LEED-certified buildings have lower operating costs and provide healthier and safer environments for occupants. It is also noted that the award of a LEED designation "demonstrate[s] an owner's commitment to environmental stewardship and social responsibility."

The addresses and postal codes of the Energy Star and LEED buildings are publicly available. We match these addresses to office buildings listed in the CoStar database. CoStar is a repository and provider of U.S. commercial real estate financial data. The CoStar database includes current rental and occupancy information as well as quality characteristics of buildings. We matched the CoStar database with the Energy Star and LEED address files as of June 2008. We found 1,360 green labeled office buildings: 1,045 buildings with an Energy Star label, 286 buildings with a LEED label, and 29 buildings with a dual certification.

\section{Control Sample}

Even if corporations base their housing decisions on the environmental characteristics of office buildings, these are not likely to be their paramount considerations. Corporations will also evaluate the quality of the building and the location of the premises. We therefore match each green building to a set of commercial office buildings that are in close proximity. In this way, we identify clusters of nearby buildings. Each cluster contains one green office building and all other office buildings within a quarter mile radius. This match yields 1,180 clusters, each containing one green building and an average of three nearby control buildings.

\section{Descriptive Statistics}

Table 1 provides more detailed information on the sample of green buildings, and on the control sample of conventional office buildings. (Variable definitions are in the Appendix Table A1). The table shows that the green buildings differ substantially on some key quality issues. For example, the 
green buildings are substantially larger, on average, than the nearby control buildings. They are also slightly taller, by about two stories. The age difference between green buildings and conventional buildings is large: Green buildings average about 24 years in age, whereas buildings in the control sample are twice as old, on average. Because they are older, the control buildings are much more likely to have been renovated than are the green buildings.

The overall quality of the green buildings is substantially higher. Seventynine percent are rated as "class A," whereas only $35 \%$ of the control buildings have that rating. Only about $1 \%$ of the green buildings are rated as "class $\mathrm{C}$," whereas more than $16 \%$ of the control buildings have this rating. A larger fraction of green buildings have on-site amenities such as retail shops, mail rooms, and exercise facilities.

The green buildings have slightly higher occupancy rates, and the variability in occupancy is lower for green buildings than for the control buildings. Green buildings are also more likely to have a net rent contract, in which the tenants pay directly for utilities.

Table 1 illustrates the importance of controlling for building quality. Corporate housing decisions are likely to be made on the basis of many of the quality characteristics presented above, and the greenness of the building is just one of these. For example, building age is an important determinant of corporate housing decisions, and given the strong relation between age and greenness, not controlling for age could lead to inaccurate inferences.

\section{Analysis}

For each green building in the sample, we recorded the names of the five largest tenants, their Standard Industry Classification (SIC) codes, and the floor space they occupied. We were also able to determine the total volume of green office space occupied by each individual firm. Similarly, we collected data on the total square footage of green office space that was occupied in each specific four-digit SIC code. ${ }^{5}$ This matching and data extraction yields a sample of 1,180 green office buildings, occupied by 3,179 different tenants. We also collected the same information on the buildings in the control sample, which includes 4,390 office buildings, with approximately 8,000 unique tenants.

\section{Results}

\section{Green Space Consumption by Firms and Industries}

Table 2 provides an overview of the green space occupied by the 20 largest tenants in the United States. Column (1) shows the green space occupied by 
Table I. Descriptive Statistics (Standard Deviations in Parentheses).

\begin{tabular}{|c|c|c|}
\hline & Green buildings & Control buildings \\
\hline Sample size & 1,180 & 4,390 \\
\hline Building size (thousands sq. ft.) & $324.08(288.92)$ & $218.69(293.67)$ \\
\hline Stories (number) & $|5.3|(13.26)$ & $13.07(12.11)$ \\
\hline \multicolumn{3}{|l|}{ Stories (\%) } \\
\hline Low $(<10)$ & $46.25(49.90)$ & $53.49(49.88)$ \\
\hline Medium (I0-20) & $26.66(44.25)$ & $25.25(43.45)$ \\
\hline High $(>20)$ & $27.08(44.47)$ & $21.27(40.93)$ \\
\hline Age (years) & $23.85(15.57)$ & $49.45(32.50)$ \\
\hline \multicolumn{3}{|l|}{ Age $(\%)$} \\
\hline Less than 10 years & |4.27(35.00) & $4.87(21.53)$ \\
\hline 10 to 20 years & $24.06(42.78)$ & $9.40(29.19)$ \\
\hline 21 to 30 years & $43.37(49.59)$ & $25.13(43.38)$ \\
\hline 31 to 40 years & $11.10(31.43)$ & I3.25 (33.90) \\
\hline More than 40 years & $7.20(25.88)$ & $47.34(49.93)$ \\
\hline \multicolumn{3}{|l|}{ Building class ${ }^{\mathrm{a}}(\%)$} \\
\hline A & $79.39(40.48)$ & $34.94(47.68)$ \\
\hline B & $19.45(39.61)$ & $48.78(49.99)$ \\
\hline C & $1.15(10.68)$ & $16.28(36.92)$ \\
\hline On-site amenities ${ }^{\mathrm{b}}(\%)$ & $71.76(45.05)$ & $49.22(50.00)$ \\
\hline Renovated buildings (\%) & $21.04(40.79)$ & $38.5 I(48.67)$ \\
\hline Asking rent (dollars/sq. ft.) & $29.84(12.98)$ & $28.14(15.60)$ \\
\hline Net rent contract ${ }^{c}(\%)$ & $5.76(23.32)$ & $3.15(17.47)$ \\
\hline Occupancy rate (\%) & $89.12(12.76)$ & $81.35(22.73)$ \\
\hline
\end{tabular}

Note. The control sample consists of all commercial office buildings within a 0.25 mile radius of each rated building for which comparable data are available.

aBuilding Classes A, B, and C are nationally standardized quality ratings of commercial property. Class $A$ is best.

bOne or more of the following amenities are available on-site: banking, convenience store, dry cleaner, exercise facilities, food court, food service, mail room, restaurant, retail shops, vending areas, fitness center.

cNet rent contracts require tenants to pay separately for utilities.

each tenant. Commercial banks, such as Wells Fargo Bank and Bank of America, are among the main green space users. These are human capital intensive financial service firms, lending support to Hypothesis 1. But this high ranking for the financial sector is partially explained by its extensive use of office space in general-the financial services industry is notoriously space intensive - which is in line with Hypothesis 2.

The oil industry seems to be well represented in green office buildings also, with tenants such as Shell and Chevron leasing a substantial percentage 


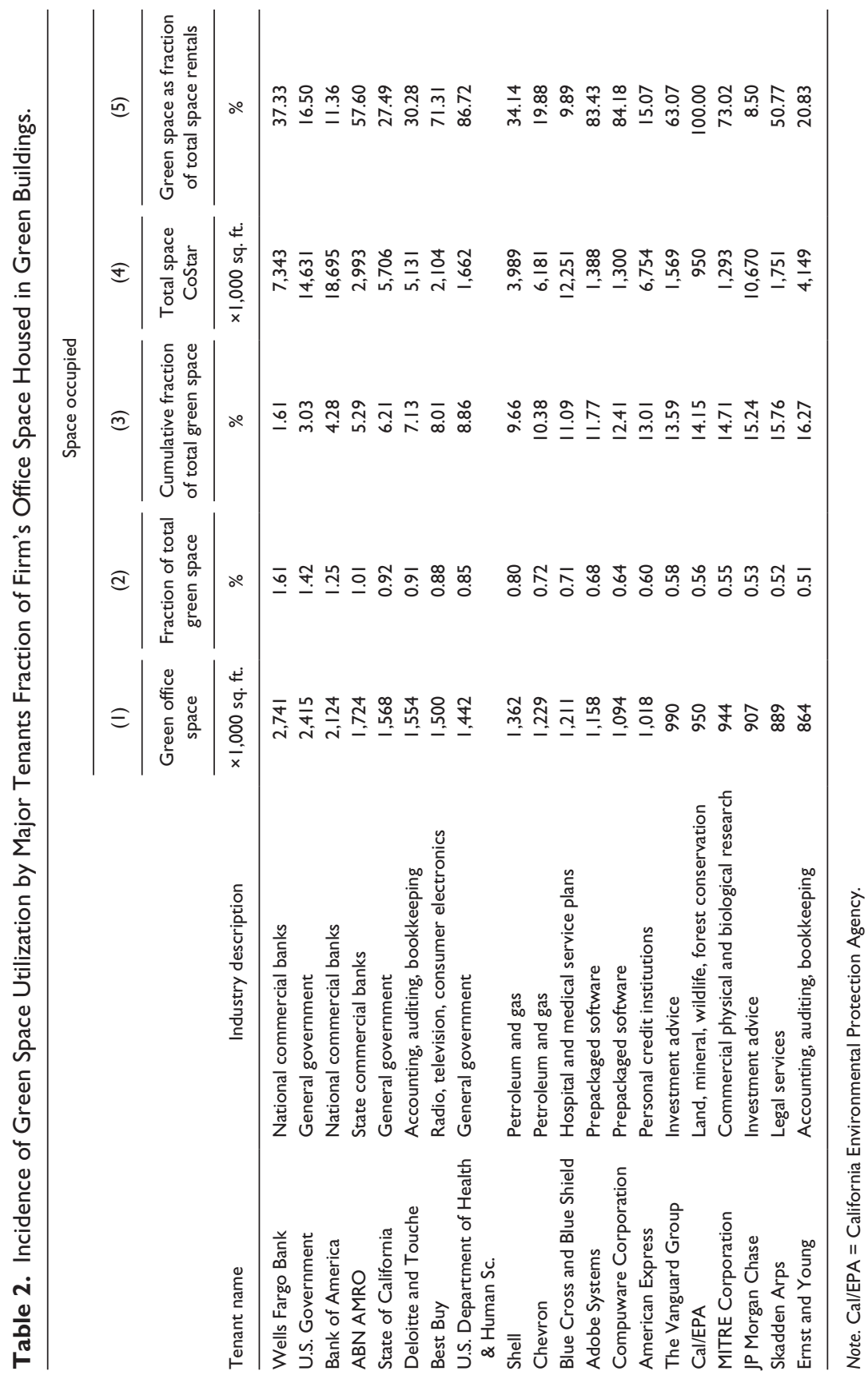


of the green building office stock. This industry presence is in line with the institutional pressure hypothesis (Hypothesis 3), where we posit that firms with environmentally sensitive operations are more inclined to lease space in green buildings. Furthermore, in support of Hypothesis 4, the U.S. Federal Government and government-related organizations, such as the Department of Health and Human Sciences and the Environmental Protection Agency, are prominent tenants of green office space.

To account for differences in office space utilization among industries, column (4) shows the total volume of office space occupied by the largest green tenants and column (5) presents the green office stock rented by each tenant, relative to the total office stock it occupies. Several trends are apparent. First, the California Environmental Protection Agency (Cal/EPA) is not only among the top 20 occupants of green office space, but all of its office stock has a green label. Indeed, the agency boasts that its headquarters building in Sacramento is equipped with state-of-the-art techniques to improve indoor air quality and to reduce energy use and that it is among the world's most energy- and resource-efficient buildings. Cal/EPA is a clear example of how non-profit or governmental organizations derive nonfinancial utility from leasing green, supporting Hypothesis 2. As mentioned on the Cal/EPA website, "This approach not only makes environmental sense, but it also makes the building a better place to visit and in which to work."

Some of the commercial banks are not only prominent tenants of green space in absolute terms but also relative to their total office stock. For example, ABN AMRO and Wells Fargo lease substantial proportions of their total office needs - 58\% and 37\%, respectively - in green buildings. For the former, the headquarters in Chicago provides the main explanation. Wells Fargo occupies several buildings with a green label. The bank has a well-articulated sustainability policy. In interviews conducted by telephone with the authors, a representative explained that ". . it is important to show our environmental focus, for example, by leasing green office space." As argued by Ramus and Montiel (2005), it is the implementation of CSR policies rather than the policy commitment that is necessary to reap direct business benefits.

For other corporations, such as Adobe Systems and Compuware, leasing green space may not be a deliberate choice, but it may merely come with a preference for high-quality office space, in combination with a growing need for space due to rapid expansion. Alternatively, the location of firm activities in green buildings may attract and retain highly qualified employees.

Finally, it is worth noting that the 20 tenants documented in Table 2 occupied, on aggregate, almost one sixth of the total inventory of green office space in the United States in June 2008. 
Although the analysis of the leading corporate consumers of green office space provides interesting perspectives on these firms' motivations, this comparison also has a drawback. As it focuses on the largest firms, it underreports firms in less concentrated industries. We therefore study the aggregate amount of green office space occupied by the largest four-digit SIC codes. These numbers are presented in Table 3. Column (1) shows the 20 industry categories with the highest aggregate of total green office space. Legal services - which include attorneys and their support staffs - are by far the largest occupant of green office space. Although only one individual tenant from the legal services industry-Skadden, Arps - is among the 20 major occupiers of green space reported in Table 2, the sector as a whole has a clear preference for sustainable office buildings. The preference of the legal services industry for more sustainable office space is in line with the economic advantage hypothesis (Hypothesis 1), wherein we posit that tenants in the tertiary sector are more likely to lease space in green buildings.

Other industry categories that are among the largest tenants of green space are public administration, national commercial banks, crude petroleum and gas, and investment advisors. This tenancy pattern is generally in line with the stylized facts documented in Table 2.

Column (5) documents green space as a percentage of total office space occupied by a sector, and shows that $60 \%$ of the space used by the crude petroleum and gas industry is green labeled. This fraction is far higher than it is for other industries and is consistent with the institutional pressure hypothesis (Hypothesis 3). For example, Chevron has recently occupied a newly developed building in Louisiana, which has been awarded a LEED Gold certification. This award "supports the company's long-standing commitment to the Gulf Coast and the state of Louisiana. The building [ ... ] provides a safe, healthy and productive workplace for up to 750 people." 6 This expression of social and environmental awareness is unrelated to Chevron's core business, but may help to improve its reputation among stakeholders.

\section{Tenant Concentration in Green Versus Non-Green Buildings}

To investigate the four hypotheses more systematically, the authors calculate the fraction of leased office space per building for each tenant in the sampled buildings. Then, we aggregate these fractions based on one-digit SIC codes for each green building and each control building. ${ }^{7}$ We consider the following one-digit SIC codes: (0) agriculture, forestry, and fishing; (1) mining and construction; (2 and 3) manufacturing; (4) transportation, communications, electric, gas, and sanitary services; (5) wholesale and retail trade; (6) finance, insurance, and real estate; (7 and 8) services; and (9) public administration. 


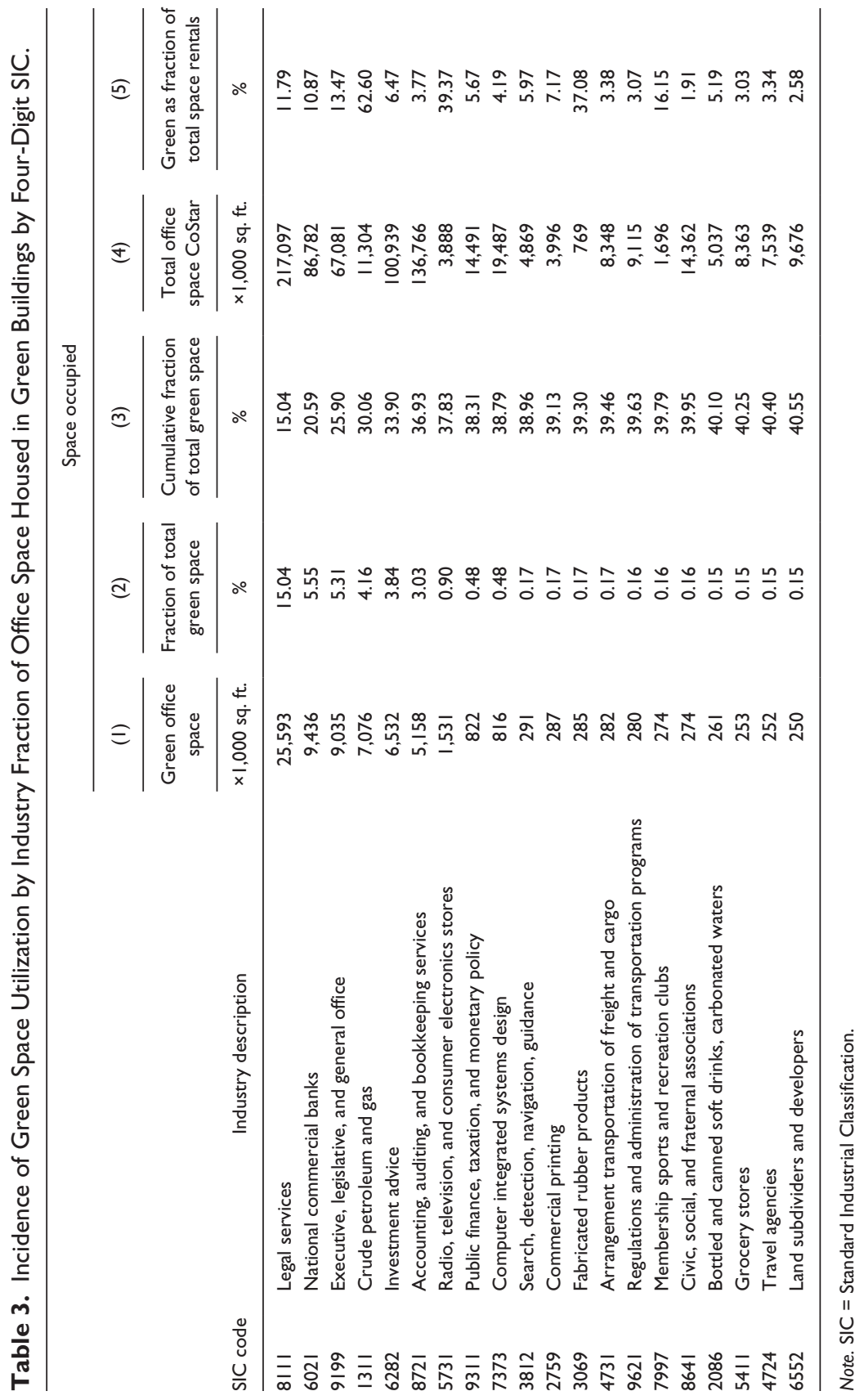


For each building, this yields the distribution of office space by major industry category, matched with the characteristics of that building - such as building age, size, and quality - and the presence of an Energy Star and/or LEED certification.

The most direct test of tenant preferences is to investigate the likelihood that certain industries systematically lease green rather than conventional office space. In Table 4, we therefore compare the fraction of office space occupied by a specific industry in a green building with the fraction occupied by the same industry in each control building in the same cluster. Using this method allows for the inclusion of all industries. ${ }^{8}$ We estimate the following equation for each one-digit SIC code:

$$
\left(O_{g n}-O_{c n}\right)=\alpha+\beta_{n}\left(X_{g n}-X_{c n}\right)+\sum_{n=1}^{N} \gamma_{n} c_{n}+\varepsilon_{n},
$$

where the dependent variable is the difference between the fraction of square footage occupied by tenants in green building $g$ in cluster $n$ and the fraction of square footage occupied by tenants in control building $c$-where $c$ is located in the same cluster. We control for building and location characteristics that are likely to influence corporate housing choices. $\left(X_{g n}-X_{c n}\right)$ is a vector of the hedonic characteristics of the green building-building age, building size, and building quality-in cluster $n$ minus the corresponding quality characteristics in the control building. The term $c_{n}$ is a dummy variable with a value of one if building $n$ is located in cluster $n$ and zero otherwise. Importantly, these location coefficients account for unobserved characteristics related to each specific location. Terms $\alpha, \beta_{n}$, and $\gamma_{n}$ are estimated coefficients and $\varepsilon_{n}$ is an error term.

Results are presented in Table 4 for ordinary least squares regression models corrected for heteroskedasticity (White, 1980). Each column header corresponds to a specific one-digit SIC industry. Given the relatively high adjusted- $R^{2} \mathrm{~s}$, the model seems to explain corporate housing decisions quite well (the locational clusters alone already explain a large part of the variation).

Holding other factors in the regression constant, the intercept indicates whether the fraction of office space occupied by tenants in a specific industry is larger (or smaller) in green office buildings as compared with conventional office buildings. For most industries, the constant is significantly negative, which indicates that tenants are more likely to lease space in conventional office buildings rather than in environmentally labeled buildings. This finding is consistent with the small fraction of the total environmentally certified 


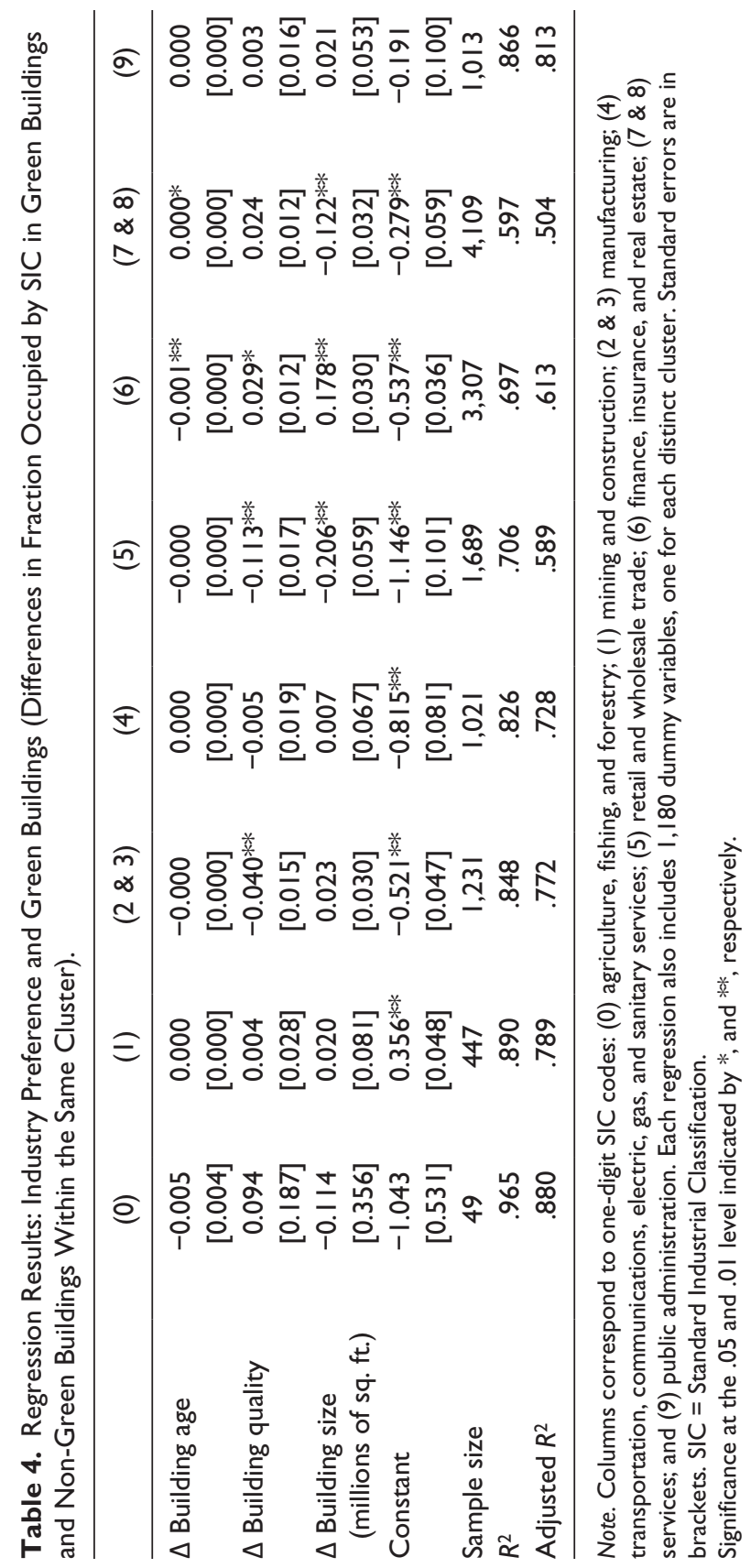


office stock. However, as in Ramus and Montiel (2005), the variation in ecological implementation (measured by green building adoption) varies significantly across industries, with the coefficient ranging from -1.043 to 0.356 .

Importantly, the exceptions to the pattern of significantly negative coefficients are the mining and construction industry - Column (1) - and the public administration sector-Column (9). The former has a significantly positive constant, which indicates that tenants in this industry group, on average, lease more office space in green buildings than in non-green office buildings, controlling for differences in building quality. This finding is in line with the institutional pressure hypothesis. The fact that the intensity of green space use is highest in this industry is surprising, as office utilization is expected to be rather limited for the mining and construction industry. But, as documented in Table 3, companies in the mining and construction industry have a large fraction of their office inventory in green buildings, which is confirmed by the results in Table 4. The tendency of "irresponsible" organizations to offset an otherwise negative corporate image by responsible "social" or "environmental" behavior is widely acknowledged in the literature (Kotchen \& Moon, 2012; Ramus \& Montiel, 2005; Strike, Gao, \& Bansal, 2006).

For the public administration sector, the difference in space occupied in green buildings relative to conventional buildings is not statistically significant. But, given the fact that we find significantly negative coefficients for six other industries, the public sector does stand out as a user of green office space. This exception is in line with the environmental responsibility hypothesis.

Columns (6) and (7 and 8) report results for the finance, insurance and real estate industry, and the services industry, respectively. Especially for these industries, which include legal services and commercial banking, one would expect that leasing space in green office buildings is rational, as perceptions about indoor air quality and human resource consideration are of major importance (Hypothesis 1) and housing costs are a significant part of operating expenses (Hypothesis 2). The results show that the coefficient on the green variable for both estimations is closer to zero than for most other industries, but it remains negative. Although descriptive evidence in Table 2 indicated that some firms in the finance and services industry are among the larger tenants of green space, a more pervasive trend toward leasing green cannot yet be documented for these industries, when controlling more directly for building and location quality. The difference between the results in Table 2 and Table 4 suggests that it is rather the larger and more visible firms that move first in the implementation of social and environmental measures, followed subsequently by the critical mass in the same industry. 
As a second test, we adapt regression Equation (1), including summary measures of variations in the average characteristics of each one-digit industry code by metropolitan area. We include a vector $Y_{n}$ of variables that measure average employee output, payroll per employee, the number of employees per establishment, and the number of establishments. These data are computed for each one-digit SIC code by Metropolitan Statistical Area. ${ }^{9}$ This leads to the following equation for each one-digit SIC code:

$$
\left(O_{g n}-O_{c n}\right)=\alpha+\beta_{n}\left(X_{g n}-X_{c n}\right)+\sum_{n=1}^{N} \gamma_{n} c_{n}+\delta_{n} Y_{n}+\varepsilon_{n}
$$

Table 5 reports the results. Data limitations prevent this analysis for three sectors: SIC code 0 (agriculture, forestry, and fishing), SIC code 1 (mining and construction), and SIC code 9 (public administration). The variables measuring differences in the average characteristics of industries across metropolitan areas - the concentration of establishments and labor productivity - are generally statistically significant. This finding suggests that there are variations in the propensity to "lease green" by industry across metropolitan areas - arising from variations in industry characteristics across metropolitan areas. This finding is in line with results documented by Cottrill (1990), Henriques and Sadorsky (1996), and Ramus and Montiel (2005), showing that the degree to which firms implement a CSR policy is, to a large extent, determined by industry characteristics.

We measure the clustering of certain industries by including a variable reporting the number of establishments for the specific industry in each metropolitan area. The coefficient on this variable is negative for the finance, insurance, real estate sector, and for the services industry. This negative coefficient implies that in areas with a higher office space density, the likelihood of leasing green office space rather than conventional office space is smaller. These locations are likely to be in, or very close to, the Central Business District (CBD), which usually has the highest location value. This result confirms previous research (Eichholtz, Kok, \& Quigley, 2010) which reports that the increased rents and market values documented for green buildings are smaller at the most desirable locations, lending support to Hypothesis 2.

The variable representing the average size of establishments, measured by the number of employees, is significantly positive for four out of five industries, which suggests a preference for green office space in larger companies. For the variable measuring the payroll per employee - a proxy for the quality of human capital - the coefficient is almost consistently positive. (And this variable varies for each industry group by metropolitan area.) The results suggest that tenants who are more dependent on high levels of human capital 
Table 5. Regression Results: Industry Preference and Green Buildings (Differences in Fraction Occupied by SIC in Green Buildings and Non-Green Buildings Within the Same Cluster).

\begin{tabular}{lccccc}
\hline & $(2 \& 3)$ & $(4)$ & $(5)$ & $(6)$ & $(7 \& 8)$ \\
\hline$\Delta$ Building age & -0.000 & 0.000 & -0.000 & $-0.001 * *$ & $0.000^{*}$ \\
& {$[0.000]$} & {$[0.000]$} & {$[0.000]$} & {$[0.000]$} & {$[0.000]$} \\
$\Delta$ Building quality & $-0.040^{* *}$ & -0.005 & $-0.113^{* *}$ & $0.029 *$ & 0.024 \\
& {$[0.015]$} & {$[0.019]$} & {$[0.017]$} & {$[0.012]$} & {$[0.012]$} \\
$\Delta$ Building size & 0.023 & 0.007 & $-0.206 * *$ & $0.178^{* *}$ & $-0.122^{* *}$ \\
(millions sq. ft.) & {$[0.030]$} & {$[0.067]$} & {$[0.059]$} & {$[0.030]$} & {$[0.032]$} \\
Employees per & $0.014^{* *}$ & $0.002^{* *}$ & -0.003 & $0.026 * *$ & $0.001 * *$ \\
establishment & {$[0.000]$} & {$[0.000]$} & {$[0.004]$} & {$[0.001]$} & {$[0.000]$} \\
Log number of & $0.152^{* *}$ & $0.225^{* *}$ & $0.135^{* *}$ & $-0.269 * *$ & $-0.371 * *$ \\
establishments & {$[0.003]$} & {$[0.004]$} & {$[0.006]$} & {$[0.009]$} & {$[0.005]$} \\
Sales per employee & $0.001 * *$ & $0.001 * *$ & $0.001 * *$ & $0.007 * *$ & $0.080^{* *}$ \\
(thousands of dollars) & {$[0.000]$} & {$[0.000]$} & {$[0.000]$} & {$[0.000]$} & {$[0.001]$} \\
Payroll per employee & $0.000^{* *}$ & 0.000 & $0.000^{* *}$ & $0.000^{* *}$ & $0.000^{* *}$ \\
(thousands of dollars) & {$[0.000]$} & {$[0.000]$} & {$[0.000]$} & {$[0.000]$} & {$[0.000]$} \\
Constant & $-0.911^{* *}$ & $-0.946 *$ & $-1.209 * *$ & $-0.064 * *$ & $-0.261 * *$ \\
& {$[0.035]$} & {$[0.080]$} & {$[0.094]$} & {$[0.021]$} & {$[0.056]$} \\
Sample size & 1,231 & 1,021 & 1,689 & 3,307 & 4,109 \\
$R^{2}$ & .85 & .83 & .71 & .70 & .60 \\
Adjusted $R^{2}$ & .77 & .73 & .59 & .61 & .50 \\
\hline
\end{tabular}

Note. Columns correspond to one-digit SIC codes: (2 \& 3) manufacturing; (4) transportation, communications, electric, gas, and sanitary services; (5) retail and wholesale trade; (6) finance, insurance, and real estate; and (7 \& 8) services. Each regression also includes I, I 80 dummy variables, one for each distinct cluster. Standard errors are in brackets. SIC = Standard Industrial Classification.

Significance at the .05 and .01 level indicated by *, and **, respectively.

are more likely to rent office space in green buildings, supporting Hypothesis 1. Moreover, the significantly positive coefficient on the variable measuring sales per employee, a common proxy for labor productivity (see, for example, Koch \& McGrath, 1996), indicates that in areas with higher employee productivity, tenants across all industries are more likely to lease green office space. More productive companies employing valuable human capital are more likely to rent space in these same buildings. Again, this finding is in line with the economic advantage hypothesis. Furthermore, although the intercept is significantly negative for the finance, insurance, and real estate industry, as well as the services industry, it is substantially closer to zero than the intercepts for other industries reported in Table 5. These differences suggest that 
firms in the financial sector and in the services industry are more likely to rent green space than firms operating in the manufacturing, transportation and communication, and trade industries, which lends further support to the economic advantage hypothesis.

\section{Discussion}

\section{Limitations and Opportunities for Future Research}

This article leads to new questions and opportunities for future research. Data limitations allow us to investigate the motivations for ecological responsiveness, as measured by corporate real estate choices, at the industry level only. Ramus and Montiel (2005) show that industry plays an important role in firms' implementation of CSR policies, and the use of green real estate can be an important factor in such implementation. However, further research will have to use more granular firm-level data, creating a more solid basis for the analysis.

Second, firm-level data would also allow for a much richer investigation into the relation between firm motivations and ecological strategy. Starik and Rands (1995) argue that to analyze the ecological sustainability of an organization, different levels of analysis are needed. This is only feasible with detailed firm-level data.

Third, this research is based on U.S. data only, and it remains to be seen whether the conclusions can be extrapolated to other countries. A recent global survey of the environmental investment practices of professional real estate investors (Bauer, Eichholtz, Kok, \& Quigley, 2011) found strong differences across countries. These differences may be related to international differences in the corporate demand for green space, suggesting that adding an international dimension to the study of green corporate real estate decisions could enrich the analysis.

\section{Conclusion}

Awareness is growing that the built environment is an important source of greenhouse gas emissions and a major consumer of energy and raw materials. The number of green commercial properties is rapidly increasing, despite the fact that the U.S. commercial property market has been severely affected by the economic crisis. On average, firms seem to be willing to pay a rental premium for green office buildings, suggesting that this development is at least partly demand-driven. Firms conscious of environmental issues seem to consider real estate choices in their ecological responsiveness. 
The authors use the information provided by building sustainability labels to address the effect of green building on financial intermediaries. We empirically test the ecological responsiveness of industries, extending Ramus and Montiel's (2005) analysis of environmental policy implementation, rather than the mere development of these policies. Our descriptive results show that firms in the legal and financial services industries lease substantial shares of green office space. This finding is consistent with the economic advantage hypothesis, because firms in these office space-intensive sectors are likely to profit most from the operational and productivity benefits of green buildings. These findings are reinforced by a regression analysis, which shows that the concentration and size of establishments, as well as the extent to which human capital is available in a metropolitan area, has a distinct influence on the use of environmentally labeled space. Again, this finding is in line with the economic motivation for the choice for green office space and the notion that labeled office space creates a high-quality labor environment.

This study's findings further show that the mining and construction industry and, more specifically, the oil industry are major users of green office space, which follows from the institutional pressure hypothesis. Firms in environmentally sensitive industries may actively incorporate sustainability in strategic decisions, such as headquarters selection, to offset negative reputation effects. However, for these decisions, economic advantage rationales related to employee productivity and attractiveness are likely to be mixed with the institutional pressure motivation, which could increase the intensity of green space consumption.

The empirical results also show that government and government-related organizations, for which non-financial utility may be more important, have a relatively strong likelihood to rent green office space. This pattern is likely to arise from the environmental responsibility motivation.

Our findings have some implications for financial intermediaries. For companies, the findings in this study clearly show that corporate leasing decisions can facilitate the implementation of an ecologically responsible strategy. The results suggest that real estate provides a tangible element of the ecological responsiveness of an industry. The magnitude of corporate real estate leases and assets is such that the costs associated with leasing and owning these properties have become second only to payroll costs in many organizations (Veale, 1989). So firms' decisions regarding green real estate use may affect their financial performance.

Our findings on ecological responsiveness and corporate real estate also have implications for asset owners and institutional investors. Firms with a poor record on sustainability risk the likelihood of being excluded from the 
portfolios of institutional investors, which may increase their cost of equity capital (Hong \& Kacperczyk, 2009). Our results show that real estate is an aspect of firms' stance on CSR, and corporate real estate decisions may therefore have an impact on firms' cost of capital. For the providers of space - often REITs - the effect of a demand-pull for more green real estate may also have implications for their ability to raise capital (Eichholtz, Kok, \& Yonder, 2013).

The literature regarding organizations and the natural environment has been silent on the decisions by corporations to integrate real estate choices into the overall environmental strategy. Yet the importance of corporate real estate is such that it has a major effect on the sustainability of the world's economic development and likely also on the financial performance of firms. Our results indicate that corporations regard the real estate they consume in ways that vary significantly across industries. The corporate choice for green real estate is predictable by theory, which suggests that managers make rational and informed decisions regarding the sustainability of the space they use. So it seems that corporate real estate is fertile ground for further exploration of the implementation of corporate environmental policies.

\section{Appendix}

Table AI. Variable Definitions.

\begin{tabular}{|c|c|}
\hline Variable & Description \\
\hline Size (thousands of square foot) & $\begin{array}{l}\text { Building size includes the usable area and its associated } \\
\text { share of the common areas }\end{array}$ \\
\hline Stories (number) & The number of floors in the building above grade \\
\hline Low $(<10)(I=$ yes $)$ & $\begin{array}{l}\text { Binary variable is } I \text { if the number of stories is below } 10 \text {, } \\
\text { and } 0 \text { otherwise }\end{array}$ \\
\hline Medium $(10-20)(\mathrm{I}=$ yes $)$ & $\begin{array}{l}\text { Binary variable is } 1 \text { if the number of stories is } 10 \text { or } \\
\text { larger, but smaller than } 20 \text {, and } 0 \text { otherwise }\end{array}$ \\
\hline High $(>20)(I=$ yes $)$ & $\begin{array}{l}\text { Binary variable is } I \text { if the number of stories is } 20 \text { or } \\
\text { larger, and } 0 \text { otherwise }\end{array}$ \\
\hline Building age (number) & $\begin{array}{l}\text { The number of years since an existing building was } \\
\text { completed. }\end{array}$ \\
\hline Less than 10 years $(I=$ yes $)$ & $\begin{array}{l}\text { Binary variable is } I \text { if the age is younger than } 10 \text { years, } \\
\text { and } 0 \text { otherwise }\end{array}$ \\
\hline 10 to 20 years $(1=$ yes $)$ & $\begin{array}{l}\text { Binary variable is } 1 \text { if the age is } 10 \text { years or older, but } \\
\text { younger than } 20 \text { years, and } 0 \text { otherwise }\end{array}$ \\
\hline 20 to 30 years $(1=$ yes $)$ & $\begin{array}{l}\text { Binary variable is I if the age is } 20 \text { years or older, but } \\
\text { younger than } 30 \text { years, and } 0 \text { otherwise }\end{array}$ \\
\hline 30 to 40 years $(1=$ yes $)$ & $\begin{array}{l}\text { Binary variable is I if the age is } 30 \text { years or older, but } \\
\text { younger than } 40 \text { years, and } 0 \text { otherwise }\end{array}$ \\
\hline
\end{tabular}




\section{Appendix (continued)}

\begin{tabular}{|c|c|}
\hline Variable & Description \\
\hline Over 40 years $(I=$ yes $)$ & $\begin{array}{l}\text { Binary variable is I if the age is } 40 \text { years or older, and } 0 \\
\text { otherwise }\end{array}$ \\
\hline Building class & $\begin{array}{l}\text { The office building class designation differentiates } \\
\text { buildings of the same building type into different } \\
\text { categories of quality. }\end{array}$ \\
\hline A (I = yes) & $\begin{array}{l}\text { In general, a class A building is an extremely desirable } \\
\text { investment-grade property with the highest quality } \\
\text { construction and workmanship, materials and systems, } \\
\text { significant architectural features, the highest quality/ } \\
\text { expensive finish and trim, abundant amenities, first } \\
\text { rate maintenance, and in an excellent location with } \\
\text { exceptional accessibility. }\end{array}$ \\
\hline$B(I=y e s)$ & $\begin{array}{l}\text { In general, a class B building offers more utilitarian } \\
\text { space without special attractions. It will typically have } \\
\text { ordinary architectural design and structural features, } \\
\text { with average interior finish, systems, and floor plans, } \\
\text { adequate systems, and overall condition. }\end{array}$ \\
\hline$C(I=$ yes $)$ & $\begin{array}{l}\text { In general, a class } C \text { building is a no-frills, older building } \\
\text { that offers basic space. The property has below- } \\
\text { average maintenance and management, a mixed or low } \\
\text { tenant prestige, and inferior elevators and mechanical/ } \\
\text { electrical systems. }\end{array}$ \\
\hline Renovated building ( $I=$ yes) & $\begin{array}{l}\text { Binary variable is I if a building has been completely } \\
\text { restored so that the existing space becomes "new" } \\
\text { space again. The date of the last major renovation is } \\
\text { tracked. Minor renovations, such as the improvement } \\
\text { of a building's lobby or exterior, are not considered full } \\
\text { building renovations. }\end{array}$ \\
\hline On-site amenities ( $(\mathrm{l}=$ yes $)$ & $\begin{array}{l}\text { Binary variable is I if the building has one or more } \\
\text { special characteristics that can enhance a property's } \\
\text { appeal, including the presence of an atrium, banking } \\
\text { facilities, concierge, convenience store, day care, } \\
\text { dry cleaner, exercise facilities, restaurant, and retail } \\
\text { shops. }\end{array}$ \\
\hline $\begin{array}{l}\text { Asking rent (dollar per square } \\
\text { foot) }\end{array}$ & $\begin{array}{l}\text { Asking rent is the weighted average rent for a building } \\
\text { or market. Rents are weighted based on the total } \\
\text { square footage available at a rental rate. If the rental } \\
\text { rate is zero, it is not counted in the average rent. } \\
\text { Average rent is calculated from suite-by-suite detail. }\end{array}$ \\
\hline Net rent contract $(\mathrm{I}=$ yes $)$ & $\begin{array}{l}\text { Binary variable is I if the building has a lease structure in } \\
\text { which the tenant is responsible for all expenses associated } \\
\text { with their proportional share of occupancy of the building. } \\
\text { This is the opposite of a gross rental contract, a rental } \\
\text { rate that includes normal building standard services that } \\
\text { are provided and paid by the landlord. }\end{array}$ \\
\hline
\end{tabular}




\section{Appendix (continued)}

\begin{tabular}{|c|c|}
\hline Variable & Description \\
\hline Occupancy rate (percent) & $\begin{array}{l}\text { Occupancy rate is defined as the square footage of space } \\
\text { that is physically occupied by a tenant as a fraction of } \\
\text { the total rentable office space. It does not include space } \\
\text { that is under a lease obligation, where the tenant does } \\
\text { not actually occupy the space. }\end{array}$ \\
\hline $\begin{array}{l}\text { Employees per establishment } \\
\text { (number) }\end{array}$ & $\begin{array}{l}\text { The total number of paid employees, which consists of } \\
\text { full- and part-time employees, including salaried officers } \\
\text { and executives of corporations, who were on the } \\
\text { payroll during the pay period including March I } 2 \text {. }\end{array}$ \\
\hline $\begin{array}{l}\text { Number of establishments } \\
\text { (natural logarithm) }\end{array}$ & $\begin{array}{l}\text { An establishment is a single physical location at which } \\
\text { business is conducted and/or services are provided. It } \\
\text { is not necessarily identical to a company or enterprise, } \\
\text { which may consist of one establishment or more. } \\
\text { When two activities or more are carried on at a single } \\
\text { location under a single ownership, all activities generally } \\
\text { are grouped together as a single establishment. }\end{array}$ \\
\hline $\begin{array}{l}\text { Sales per employee (thousands } \\
\text { of dollars) }\end{array}$ & $\begin{array}{l}\text { Includes gross receipts from customers or clients for } \\
\text { services provided, from the use of facilities, and from } \\
\text { merchandise sold during the census year, whether or not } \\
\text { payment was received in the year. Calculated as a fraction } \\
\text { of the total number of paid employees, which consists of } \\
\text { full- and part-time employees, including salaried officers } \\
\text { and executives of corporations, who were on the payroll } \\
\text { during the pay period including March I } 2 \text {. }\end{array}$ \\
\hline $\begin{array}{l}\text { Payroll per employee (dollars, } \\
\text { natural logarithm) }\end{array}$ & $\begin{array}{l}\text { Payroll includes all forms of compensation such as } \\
\text { salaries, wages, commissions, dismissal pay, bonuses, } \\
\text { vacation allowances, sick-leave pay, and employee } \\
\text { contributions to qualified pension plans paid during the } \\
\text { year to all employees. Divided by the total number of } \\
\text { paid employees, which consists of full- and part-time } \\
\text { employees, including salaried officers and executives of } \\
\text { corporations, who were on the payroll during the pay } \\
\text { period including March } 12 \text {. }\end{array}$ \\
\hline
\end{tabular}

Sources. CoStar Group and Census.gov

\section{Acknowledgments}

The authors thank the editors, two anonymous referees, Tima Bansal, Andrew King, Daniela Kirchberg, and participants at seminars at UC Berkeley and Maastricht University for useful comments.

\section{Authors' Note}

We mourn the passing of John M. Quigley in May 2012. John was a great scholar, colleague, and friend, and he was actively involved in crafting this project. We hope that the resulting article lives up to his expectations. 


\section{Declaration of Conflicting Interests}

The author(s) declared no potential conflicts of interest with respect to the research, authorship, and/or publication of this article.

\section{Funding}

The author(s) disclosed receipt of the following financial support for the research, authorship, and/or publication of this article: Financial support for this research has been provided by the European Centre for Corporate Engagement, Maastricht University, and by the Royal Institution of Chartered Surveyors (RICS). Professor Kok was supported by a VENI grant from the Dutch Science Foundation (NWO) while doing the research for doing this article.

\section{Notes}

1. Real estate investments are the most significant alternative asset class for institutional investors: on average, pension funds invest about $5 \%$ of assets in real estate (average allocations to private equity and hedge funds are $4.00 \%$ and $3.23 \%$, respectively), and according to an annual survey by Pensions \& Investments, worldwide real estate assets under management by tax-exempted institutions peaked in June 2008 at \$1 trillion (Andonov, Eichholtz, \& Kok, 2013).

2. Energy Star is the energy-efficiency certification system of the U.S. Environmental Protection Agency and U.S. Department of Energy, and Leadership in Energy and Environmental Design (LEED) is the system of the U.S. Green Building Council, a non-profit industry group.

3. Evidence on the relative performance of socially responsible investments (SRI) is rather inconclusive. Heinkel, Kraus, and Zechner (2001) and Hong and Kacperczyk (2009) show that precisely the presence of ethical investors drives the prices of irresponsible companies lower, thereby increasing their expected total returns. Derwall, Guenster, Bauer, and Koedijk (2005) and Guenster, Bauer, Derwall, and Koedijk (2009) show positive risk-adjusted stock market performance related to corporate "eco-efficiency." See Renneboog, Ter Horst, and Zhang (2008) for a recent literature review.

4. The six main characteristics of building sustainability according to LEED are the following: sustainable sites, water efficiency, energy and atmosphere, materials and resources, indoor environmental quality, and innovation. A LEED certificate is awarded based on the aggregate score, where the level of the award can range from Certified (pass) to Platinum (excellent). There are separate programs for existing buildings and newly developed buildings.

5. The totals of green office space occupied by individual tenants or industry groups are probably underestimated, as CoStar covers approximately $80 \%$ of the U.S. commercial property market. Moreover, tenant data are not available for all green office buildings.

6. Chevron Press Release, May 2008.

7. We use one-digit Standard Industrial Classification (SIC) code aggregates rather than two-, three-, or four-digit SIC codes, as these would not yield a reasonable number of observations per industry. 
8. In a previous version of the paper, the authors analyzed the propensity to lease green space for a specific industry, using a Tobit model. However, the data did not have enough observations for SIC code 0 (agriculture, forestry, and fishing) and SIC code 1 (mining and construction), and we were forced to exclude these industries from the Tobit analysis.

9. The raw data were obtained from the Office of Advocacy, U.S. Small Business Administration (based on data provided by the U.S. Census Bureau for 1997).

\section{References}

Andonov, A., Eichholtz, P. M. A., \& Kok, N. (2013). A global perspective on pension fund investments in real estate. Journal of Portfolio Management, 39(5), 32-42.

Aragón-Correa, E., \& Rubio-López, J. (2007). Proactive corporate environmental strategies: Myths and misunderstandings. Long Range Planning, 40, 357-381.

Bansal, P., \& Clelland, I. (2004). Talking trash: Legitimacy, impression management, and unsystematic risk in the context of the natural environment. Academy of Management Journal, 47, 93-103.

Bansal, P., \& Roth, K. (2000). Why companies go green: A model of ecological responsiveness. Academy of Management Journal, 43, 717-737.

Barnea, A., Heinkel, R., \& Kraus, A. (2005). Green investors and corporate investment. Structural Change and Economic Dynamics, 16, 332-346.

Bassen, A., Hölz, H.-M., \& Schlange, J. (2006). The influence of corporate responsibility on the cost of capital: An empirical analysis. Hamburg, Germany: University of Hamburg. Retrieved from http://www.dsw-info.de/uploads/media/ Bassen.pdf

Bauer, R., Eichholtz, P. M., Kok, N., \& Quigley, J. M. (2011). How green is your property portfolio? The global real estate sustainability benchmark. Rotman International Journal for Pension Management, 4(1), 34-43.

Bauer, T. N., \& Aiman-Smith, L. (1996). Green career choices: The influences of ecological stance on recruiting. Journal of Business and Psychology, 10, 445-458.

Cottrill, M. T. (1990). Corporate social responsibility and the marketplace. Journal of Business Ethics, 9, 723-729.

Danna, K., \& Griffin, R. W. (1999). Health and well-being in the workplace: A review and synthesis of the literature. Journal of Management, 25, 357-384.

Derwall, J., Guenster, N., Bauer, R., \& Koedijk, K. (2005). The eco-efficiency premium puzzle. Financial Analysts Journal, 61(2), 51-63.

Derwall, J., \& Verwijmeren, P. (2007). Corporate governance and the cost of equity capital: evidence from GMI's governance rating. ECCE Research Note, Maastricht University.

Edmans, A. (2011). Does the stock market fully value intangibles? Employee satisfaction and equity prices. Journal of Financial Economics, 101, 621-640.

Edwards, B. (2006). Benefits of green offices in UK: Analysis from examples built in the 1990s. Sustainable Development, 14, 190-204.

Eichholtz, P. M. A., Kok, N., \& Quigley, J. M. (2010). Doing well by doing good: Green office buildings. American Economic Review, 100, 2494-2511. 
Eichholtz, P. M. A., Kok, N., \& Quigley, J. M. (2013). The economics of green building. Review of Economics and Statistics, 95, 50-63.

Eichholtz, P. M. A., Kok, N., \& Yonder, E. (2012). Portfolio greenness and the financial performance of REITs. Journal of International Money and Finance, 31, 1911-1929.

Eichholtz, P. M. A., Kok, N., \& Yonder, E. (2013). Operating efficiency and the cost of debt: The case of REITs. Maastricht, The Netherlands: University of Maastricht.

Fombrun, C., \& Shanley, M. (1990). What's in a name? Reputation building and corporate strategy. Academy of Management Journal, 33, 233-258.

Gatewood, R. D., Gowan, M. A., \& Lautenschlager, G. J. (1993). Corporate image, recruitment image, and initial job choice decisions. Academy of Management Journal, 36, 414-427.

Guay, T., Doh, J. T., \& Sinclair, G. (2004). Non-governmental organizations, shareholder activism, and socially responsible investments: Ethical, strategic, and governance implications. Journal of Business Ethics, 52, 125-139.

Guenster, N., Bauer, R., Derwall, J., \& Koedijk, K. (2011). The economic value of corporate eco-efficiency. European Financial Management, 17, 679-704.

Heinkel, R., Kraus, A., \& Zechner, J. (2001). The effect of green investments on corporate behavior. Journal of Financial and Quantitative Analysis, 36, 431-449.

Henriques, I., \& Sadorsky, P. (1996). The determinants of an environmentally responsive firm: An empirical approach. Journal of Environmental Economics and Management, 30, 381-395.

Henriques, I., \& Sadorsky, P. (1999). The relationship between environmental commitment and managerial perceptions of stakeholder importance. Academy of Management Journal, 42, 87-99.

Hoffman, R. E., Wood, R. C., \& Kreiss, K. (1993). Building-related asthma in Denver office workers. American Journal of Public Health, 83, 89-93.

Hong, H., \& Kacperczyk, M. (2009). The price of sin: The effects of social norms of markets. Journal of Financial Economics, 93, 15-36.

Kahn, M. E. (2007). Do greens drive Hummers or hybrids? Environmental ideology as a determinant of consumer choice. Journal of Environmental Economics and Management, 54, 129-145.

Karpoff, J., Lott, J. R., \& Rankine, G. (1999). Environmental violations, legal penalties, and reputation costs. Chicago, IL: University of Chicago Law School Working Paper. Retrieved from http://www.law.uchicago.edu/files/files/71. Lott_.Environment.pdf

Kats, G. (2003). Green buildings costs and financial benefits. Boston, MA: Massachusetts Technology Collaborative. Retrieved from http://communitywealth.org/content/green-building-costs-and-financial-benefits

Klassen, R. D., \& McLaughlin, C. P. (1996). The impact of environmental management on firm performance. Management Science, 42, 1199-1214.

Koch, M. J., \& McGrath, R. G. (1996). Improving labor productivity: Human resource management policies do matter. Strategic Management Journal, 17, 335-354. 
Kok, N., McGraw, M., \& Quigley, J. M. (2011). The diffusion of energy efficiency in building. American Economic Review: Papers and Proceedings, 101(3), 77-82.

Konar, S., \& Cohen, M. A. (2001). Does the market value environmental performance? Review of Economics and Statistics, 83, 281-289.

Kotchen, M. J., \& Moon, J. J. (2012). Corporate social responsibility for irresponsibility. The B.E. Journal of Economic Analysis \& Policy, 12(1), Article 55. Retrieved from http://environment.yale.edu/kotchen/pubs/csrcsi.pdf

Linnenluecke, M. K., \& Griffiths, A. (2010). Corporate sustainability and organizational culture. Journal of World Business, 45, 357-366.

Milgrom, P., \& Roberts, J. (1986). Price and advertising signals of product quality. Journal of Political Economy, 94, 796-821.

Mitchell, R. K., Agle, B. R., \& Wood, D. J. (1997). Toward a theory of stakeholder identification and salience: Defining the principle of who and what really counts. Academy of Management Review, 22, 853-886.

Nelson, A. J. (2007, November). The greening of U.S. investment real estate-Market fundamentals, prospects and opportunities (RREEF Research, No. 57). Retrieved from http://mts.sustainableproducts.com/Capital_Markets_Partnership/Business Case/SO_57_Greening_of_US_Investment_RE.pdf

Palmer, K., Oates, W., \& Portney, P. (1995). Tightening environmental standards: The benefit-cost or the no-cost paradigm? Journal of Economic Perspectives, 9(4), 119-132.

Porter, M. E., \& Van der Linde, C. (1995, September-October). Green and competitive: Ending the stalemate. Harvard Business Review, 73(5), 120-134.

Ramus, C. A., \& Montiel, I. (2005). When are corporate environmental policies a form of greenwashing? Business \& Society, 44, 377-414.

Renneboog, L., Ter Horst, J., \& Zhang, C. (2008). Socially responsible investments: Institutional aspects, performance, and investor behavior. Journal of Banking \& Finance, 32, 1723-1742.

Social Investment Forum. (2007). Report on socially responsible investing trends in the United States. Washington, DC: Author. Retrieved from http://www.ussif. org/files/Publications/07_Trends_\%20Report.pdf

Spicer, B. H. (1978). Investors, corporate social performance and information disclosure: An empirical study. The Accounting Review, 53(1), 94-111.

Starik, M., \& Rands, G. P. (1995). Weaving an integrated web: Multilevel and multisystem perspectives of ecologically sustainable organizations. Academy of Management Review, 20, 908-935.

Strike, V. M., Gao, J., \& Bansal, P. (2006). Being good while being bad: Social responsibility and the international diversification of US firms. Journal of International Business Studies, 37, 850-862.

Veale, P. R. (1989). Managing corporate real estate: Current executive attitudes and prospects for an emergent management discipline. Journal of Real Estate Research, 4(3), 1-22.

White, H. (1980). A heteroskedasticity-consistent covariance matrix estimator and a direct test for heteroskedasticity. Econometrica, 48, 817-838. 
Wood, D. J. (1991). Corporate social performance revisited. Academy of Management Review, 16, 691-718.

Zingales, L. (2000). In search of new foundations. Journal of Finance, 55, 1623-1653.

\section{Author Biographies}

Piet M. A. Eichholtz, PhD in Finance, Maastricht University, the Netherlands, is professor in finance and real estate at the School of Business and Economics of Maastricht University, the Netherlands. Most of his work concerns real estate markets, with a focus on international investment, portfolio management, and housing markets. His research has been published in peer-reviewed academic journals such as the American Economic Review, Financial Analysts Journal, Journal of International Money and Finance, and Real Estate Economics.

Nils Kok, PhD in Finance, Maastricht University, the Netherlands, is associate professor in finance and real estate at the School of Business and Economics of Maastricht University, the Netherlands. His work focuses on the intersection of finance and energy efficiency in the real estate sector. His research has appeared in leading academic journals such as the American Economic Review, Journal of Public Economics, and Review of Economics and Statistics, and in media such as The Wall Street Journal and The Washington Post.

John M. Quigley was the I. Donald Terner Distinguished Professor at the University of California, Berkeley, where he directed Berkeley's Program on Housing and Urban Policy. He held professorial appointments in the Department of Economics, the Goldman School of Public Policy, and the Haas School of Business. His recent research was on the integration of mortgage and financial markets, urban labor markets, and local public finance. He was the editor of Regional Science and Urban Economics, and he served on the editorial boards of 11 other scholarly journals. He served as President of the American Real Estate and Urban Economics Association in 1998 and was a Fellow of the Homer Hoyt Institute. 